\title{
Imagens e deslocamentos: fotografias como enunciação de saberes, culturas e afetos
}

\section{GEOÉSLEY JOSÉ NEGREIROS MENDES \\ MAILSA CARLA PINTO PASSOS \\ STELA GUEDES CAPUTO}

\section{Resumo}

Este artigo discute a proposta de duas exposições fotográficas no âmbito de um Seminário Internacional de Educação. Temos como objetivo dialogar tanto com as imagens que essas fotografias nos dão a conhecer, quanto com as propostas dos pesquisadores realizadores dos projetos fotográficos, do Programa de Pós-Graduação em Educação da Universidade do Estado do Rio de Janeiro (UERJ). A primeira, que consiste em pesquisa de mais de 20 anos sobre a criança no universo religioso do Candomblé, e a segunda com fotos produzidas por 12 estudantes de Guiné Conacri, material produzido no âmbito de uma pesquisa de Mestrado. 


\section{Images and displacements: photographs as enunciation of knowledges, cultures and affections}

\section{GEOÉSLEY JOSÉ NEGREIROS MENDES \\ MAILSA CARLA PINTO PASSOS \\ STELA GUEDES CAPUTO}

Keywords:

Photographic images,

daily life, educational networks 


\section{Imágenes y desplazamientos: foto- grafías como enunciación de saberes, culturas y afectos}

\author{
GEOÉSLEY JOSÉ NEGREIROS MENDES \\ MAILSA CARLA PINTO PASSOS \\ STELA GUEDES CAPUTO
}

\section{Resumen}

Este artículo discute la propuesta de dos exposiciones fotográficas en el ámbito de un Seminario Internacional de Educación. Nuestro objetivo es dialogar tanto con las imágenes que esas fotografías nos hacen conocer, como con las propuestas de los investigadores realizadores de los proyectos fotográficos del Programa de Pos-Graduación en Educación de la Universidade do Rio de Janeiro (UERJ). La primera consiste en investigaciones de más de 20 años sobre los niños en el universo religioso del Candomblé y la segunda consiste en fotos producidas por 12 estudiantes

Palabras-clave: Imágenes fotográficas, cotidiano, redes educativas de Guiné Conacri, material producido en el ámbito de una investigación de Maestría. 
As fotografias conferem importância aos acontecimentos e os tornam memoráveis.

Susan Sontag

\section{Projetos envolvendo fotografias como narrativas: a proposta de uma exposição}

Em junho de 2015, por ocasião da realização do "VIII Seminário As Redes Educativas e as tecnologias: Movimentos Sociais e Educação" - promovido pela Faculdade de Educação da Universidade do Estado do Rio de Janeiro (UERJ) -, a comissão de organização decidiu realizar - como parte das atividades culturais do evento - duas exposições fotográficas que tinham em comum tanto crianças como produtores das imagens como "heróis"/"heroínas" das mesmas.

Este artigo tem como objetivo apresentar e discutir teoricamente ambas as exposições e suas propostas, no sentido de dialogar tanto com as imagens que essas fotografias nos dão a conhecer, como com as propostas daqueles que realizaram os projetos fotográficos - suas questões de pesquisa, sua intenção com a produção dessas imagens. A primeira delas, "Crianças de terreiros nas redes de educação", de Stela Guedes Caputo que consiste em pesquisa de mais de 20 anos sobre a criança no universo religioso do Candomblé. E a segunda, "Nakirigrafias: narrativas de uma África", de Curadoria e Projeto de Geoésley Negreiros Mendes, com fotos produzidas por 12 estudantes da Escola III de Forecariá - Guiné-Conacri, África, fruto de uma pesquisa de Mestrado defendida no Programa de Pós-Graduação em Educação da UERJ, orientada por Mailsa Carla Pinto Passos.

Em tempos de saturação de imagens, projetar/selecionar o que se quer registrar, realizar o registro como forma de narrar sua pesquisa, e por fim decidir como apresentar pessoas e culturas 
para além dos estereótipos e das simplificações, é opção político-epistemológica, de quem está investindo no diálogo com um outro, em atitude responsiva e responsável (BAKHTIN, 2003) em relação a este outro, no processo de produção de ciência.

Temos como pressuposto nessa discussão, primeiramente que as fotografias são "sistemas de pensamento", são "fenômeno pensante" (SAMAIN, 2012), expressão de um, ou mais modos de pensar, e, portanto, como evento político, já que se realiza na escolha daquilo - quem, o quê - quando se vai fotografar, e na apropriação dessas escolhas por aqueles que vêem a(s) imagen(s) na fotografia, e que se apropriam dela(s) no movimento de pensar/ sentir/conhecer o mundo. Fotografias, como dispositivo técnico de se fazer aparecer imagens (luzes/histórias/saberes) têm sido pensadas por nós como articulação de tempo e espaço dialogados e produtores de sentidos na sua constante incompletude.

A fotografia é uma forma de enunciação - daquele que a produz - estabelecendo diálogo com a experiência e o desejo daquele que a vê. Portanto, guarda a potência de um encontro, que longe de ser sempre harmônico e sem conflito, é sempre mobilizador de afetos, tensões e deslocamentos dos sujeitos que o experienciam (PASSOS, 2014). O encontro tem um caráter dialógico, no sentido atribuído por Bakhtin (2003). É construído na relação com o outro, numa alternância de posições e de "vozes", onde um lado que enuncia já pressupõe o outro do discurso. Aquele que fotografa pressupõe no ato, aquele que vai dialogar com sua foto. Aquele/Aquilo que é fotografado será também um integrante desse diálogo. Como pensar essa relação como produtora de afetos e deslocamentos?

Isso em especial aqui, nessas duas propostas, que têm em comum, crianças de universos culturais distintos como fotógrafos e fotografados. Essas imagens nos deslocam a um universo de afetos e saberes, mobilizado por essas narrativas que elas constroem em diálogo com essas crianças e o que elas têm a nos ensinar. Por fim, é disso que tratam essas duas propostas: O que essas crianças nos ensinam? Como elas nos ensinam? Como elas pensam com essas imagens e como as pensamos quando as fotografamos?

\section{Algumas questões sobre fotografar crianças de terreiros}

A primeira exposição fotográfica realizada no "VIII Seminário As Redes Educativas e as tecnologias: Movimentos Sociais e Educação" reuniu 40 imagens de crianças de terreiros, feitas 
por Stela Guedes Caputo. Seguiremos então com o mesmo pressuposto a respeito da fotografia enunciada no início desse nosso texto. Dissemos compreender a fotografia como um "fenômeno pensante" (SAMAIN, 2012), como expressão de um, ou mais modos de pensar, e, portanto, como evento político, já que se realiza na escolha daquilo - quem, o quê - quando se vai fotografar.

Nossa escolha: "crianças de candomblé”, não é gratuita. Já há muito escolhemos vivenciar em nossas pesquisas os saberes e as criações de sentidos das crianças de terreiros nos terreiros. Acreditamos que as crianças de terreiros foram desprezadas pelas clássicas etnografias sobre o candomblé, inclusive imageticamente. Já na área da educação, os raríssimos estudos em que estas crianças apareceram também não tratam do que priorizamos, como dissemos: as crianças, os jovens de candomblé como sujeitos de si, protagonistas nas nossas pesquisas, também nas imagens, partilhando como aprendem, como ensinam, como criam sentidos em suas vidas nos cotidianos dos terreiros em diversos estados brasileiros.

Quando iniciamos nossas pesquisas, em 1992, já demarcamos uma importante diferença que teria significado vital para a continuação de nossos trabalhos. Ao narrar o primeiro contato que tivemos com o que seria um encontro de pesquisa inesgotável, dissemos:

Os pés ainda pequenos não são empecilho para o gingado. As mãos nem bem desenvolveram e já dominam a arte de bater os atabaques. O yorubá, uma língua africana, não é mais segredo e as palavras são proferidas naturalmente. Nos terreiros da Baixada, as crianças misturam-se aos adultos, convocando os orixás através do canto e da dança”. (Jornal O Dia, 25 de outubro de $1992^{2}$ ).

Acreditamos que esta matéria (que ocupou uma página inteira) seja o primeiro documento público a enfatizar os conhecimentos das crianças de candomblé (como aprendem e ensinam a tocar, a dançar, como ocupam cargos na hierarquia do culto, como são iniciados, como se preparam para incorporar os Orixás, como aprendem e ensinam a fazer a comida ritual, como usam o yorubá, um dos 250 idiomas falados, ainda hoje, na Nigéria, como significam a si mesmas e o mundo, entre outros saberes). Obviamente, essas questões foram tratadas dentro dos limites de uma matéria de jornal, não são aprofundadas, trazem algumas informações imprecisas e termos 
não muito adequados (hoje sabemos). O mais importante, porém, é que trata-se do primeiro documento a evidenciá-las como protagonistas de pesquisas em candomblés e, principalmente, ouvindo as próprias crianças³. Quando quisemos saber como o já ogan Ricardo Nery, então com 4 anos de idade, aprendeu a tocar atabaques, perguntamos ao próprio menino, que respondeu: "Eu aprendi sozinho, só de olhar".

Resgatamos outro elemento fundamental na matéria publicada há 23 anos e que nos interessa particularmente no que escrevemos agora: texto e fotografias trabalharam juntos para contar a história das crianças entrevistadas. Se antes as crianças de candomblé não interessavam nem à antropologia, história ou à educação. Nessa matéria, quatro fotos grandes destacavam sua importância com imagens coloridas exibindo seus atabaques, seus fios de conta, ojás (pano de cabeça), batas, saias e artefatos religiosos. Seus rostos e gestos a encarar o leitor dizendo: estamos aqui e há muito tempo.

Para nós que, desde então, nunca mais saímos de perto das crianças de terreiros, já estavam ali, na matéria publicada em 1992, os atos de observar, ouvir, e fotografar. Vivências de pesquisas que seriam amadurecidas e que não oporiam texto e fotografia, escrita e imagem. É sobre o entrelaçamento de texto e fotografias que seguiremos falando, sem a menor pretensão de aprofundar o assunto.

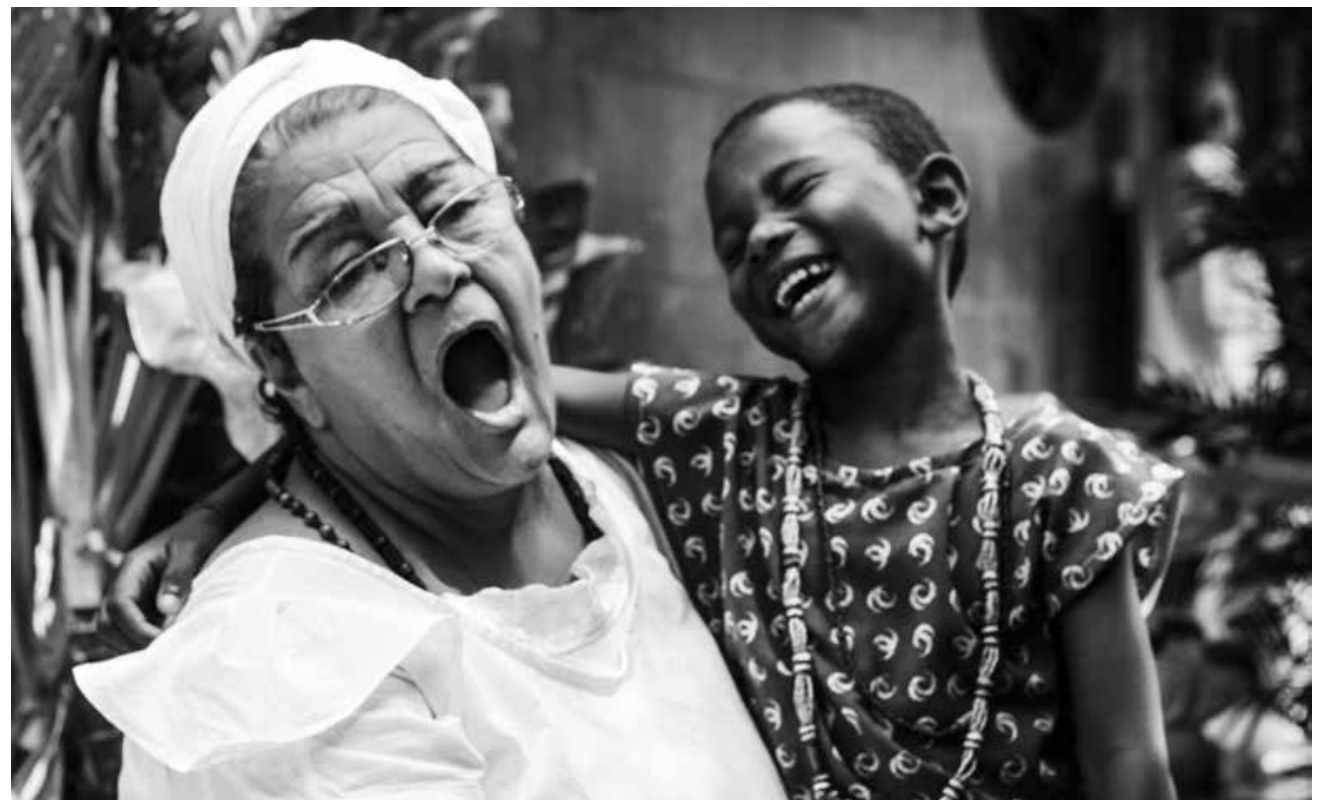


Fruto do esforço de várias áreas do saber (física, química e engenharia, por exemplo), a fotografia também é um fenômeno multipolêmico desde aquele agosto de 1839, quando Daguerre provou ao mundo que podia fixar imagens em uma placa metálica deixando a luz entrar em uma câmara escura. Era pecado, pois só Deus poderia produzir ou reproduzir o rosto humano, assim considerou a Igreja. Não era arte, já que os domínios complexos do chamado fazer artístico só aos pintores e escultores pertenciam. Podemos ver o efeito do ódio despertado pela fotografia ao lermos trechos da carta de Baudelaire, escrita 20 anos após o seu surgimento, ao diretor da Revue Française, sobre o salão de 1859, para ele são dias "deploráveis em que a nova indústria muito contribuirá para confirmar a idiotice da fé que nela se tem, e para arruinar o que poderia restar de divino no espírito francês". E continua:

Essa multidão idólatra postulou um ideal digno de si e apropriado à sua natureza, isso está claro. Em matéria de pintura e de escultura, o credo atual do povo, sobretudo na França (e não creio que alguém ouse afirmar o contrário) é este: "creio na natureza e creio somente na natureza (há boas razões para isso). Creio que a arte é e não pode ser outra coisa além da reprodução exata da natureza (um grupo tímido e dissidente reivindica que objetos de caráter repugnante sejam descartados, como um penico ou um esqueleto). Assim, o mecanismo que nos oferecer um resultado idêntico à natureza será a arte absoluta". Um Deus vingador acolheu as súplicas desta multidão. Daguerre foi seu Messias. E então ela diz a si mesma: "Visto que a fotografia nos dá todas as garantias desejáveis de exatidão (eles crêem nisso, os insensatos), a arte é a fotografia”. A partir desse momento, a sociedade imunda se lança, como um único Narciso, à contemplação de sua imagem trivial sobre o metal. Uma loucura, um fanatismo extraordinário se apodera de todos esses novos adoradores do sol. Estranhas aberrações se produzem. Associando e reunindo homens desajeitados e mulheres desavergonhadas, afetados como os açougueiros e as lavadeiras no carnaval, pedindo a seus heróis que continuem a fazer suas caretas de circunstância pelo tempo necessário à tomada, eles se lisonjeiam de oferecer cenas, trágicas e graciosas, da história antiga. (BAUDELAIRE, 1859 apud ENTLER, 2007, p. 11).

Baudelaire via na indústria fotográfica o refúgio dos pintores fracassados e ordenava, quase em desespero, que a fotografia retornasse ao que considerava seu verdadeiro dever: 
[...] que é o de ser a serva das ciências e das artes, a mais humilde das servas, como a imprensa e a estenografia, que nem criaram e nem suplantaram a literatura. Que ela enriqueça rapidamente o álbum do viajante e devolva a seus olhos a precisão que faltava a sua memória, que ela ornamente a biblioteca do naturalista, amplie os animais microscópicos, ou mesmo, que ela acrescente ensinamentos às hipóteses do astrônomo, que ela seja enfim a secretária e o guarda-notas de quem quer que precise, em sua profissão, de uma absoluta precisão material, até aí, nada melhor. Que ela salve do esquecimento as ruínas decadentes, os livros, as estampas e os manuscritos que o tempo devora, as coisas preciosas cuja forma irá desaparecer e que pedem um lugar no arquivo de nossa memória, ela terá nossa gratidão e será ovacionada. Mas se lhe for permitido usurpar o domínio do impalpável e do imaginário, de tudo aquilo que apenas tem valor porque o homem lhe acrescenta alma, então, que desgraça a nossa! (BAUDELAIRE 1859 apud ENTLER, 2007, p.12).

Alheio à polêmica que provocava e muito antes do poeta francês lançar seus apelos para que a fotografia fosse "apenas uma serva documental", no mesmo 1839, o daguerreótipo viaja. A invenção é levada em sua primeira expedição pelo mundo passando, inclusive, por Recife, Salvador, Rio de Janeiro e Santos, em 1840, inscrevendo-se não na sentença de Baudelaire, mas na disputa de sentidos, destino que jamais a abandonaria.

Essa viagem teve início já com a expectativa de ser a primeira expedição ao redor do mundo utilizando a fotografia como meio de registro. O pioneirismo da experiência e todos os desdobramentos culturais, políticos e econômicos do empreendimento evidenciam sua singularidade nas relações internacionais da primeira metade do século XIX. (TURAZZI, 2010, p.19).

Ora, a fotografia mal começou a engatinhar e já topava com todas as polêmicas que a envolveriam até os nossos dias. Dubois (2006) define três posições epistemológicas a respeito das imagens fotográficas e o realismo. A primeira posição, diz ele, vê na foto uma reprodução mimética, revelando similaridade e autenticidade, a foto é, portanto, um espelho do mundo; a segunda posição denuncia a primeira, já que a fotografia é sempre uma interpretação-transformação do real. Para o autor, que, na verdade, está dialogando com Charles Sanders 
Peirce e sua noção de índice, a terceira posição marca um retorno ao referente, mas sem a obsessão do que ele chama de ilusionismo mimético.

Essa referencialização da fotografia inscreve o meio do campo de uma pragmática irredutível: a imagem foto torna-se inseparável de sua experiência referencial, do ato que a funda. Sua realidade primordial nada diz além de uma afirmação de existência. A foto é em primeiro lugar índice. Só depois ela pode torna-se parecida (ícone) e adquirir sentido (símbolo). (DUBOIS, 2006, p. 53).

Interessante nessa perspectiva de Dubois é que ela não absolutiza o referente, como Barthes, para quem: "A fotografia não rememora o passado. O efeito que ela produz em mim não é o de restituir o que é abolido (pelo tempo, pela distância), mas o de atestar que o que vejo de fato existiu". (BARTHES, 1984, p.123).

É por isso que Novaes (2005) lembra que para Barthes, a imagem está ligada à raiz de imitare, vista, portanto, como representação analógica no sentido de re-apresentação, ou cópia do real. Mas, Novaes também explica que os linguistas se perguntam se haveria um código analógico, por oposição a outros códigos como fonemas e linguagem gestual, estes sim campos insuspeitos de análise linguística. A questão colocada pela antropóloga, mais uma vez aponta as dicotomias dessa discussão: "se para uns a imagem é um sistema muito rudimentar em relação à língua, para outros a significação não pode esgotar a riqueza indizível da imagem. Como dizer o indizível, como tornar inteligível aquilo que é, antes de mais nada, do domínio do sensível?"(NOVAES, 2005, p. 108).

Ainda que sem uma posição unânime, a antropologia, diz Novaes, acompanhou de perto todo o desenvolvimento da fotografia e do cinema lembrando que filmes etnográficos são realizados desde o início do século XX, além das pesquisas também com fotografias nos trabalhos precursores de Malinowski (1922). A autora destaca, ainda, a importância dos trabalhos de Margaret Mead e Gregory Bateson, que, na década de 1940 buscaram aprofundar as possibilidades de trabalho com a imagem no campo antropológico. Contudo, de acordo com Novaes, o valor do trabalho documental sobre recursos imagéticos e não textuais continua sendo pouco explorado e mesmo contestado em vários círculos acadêmicos, já que os textos escritos são considerados mais ricos em informação do que as imagens. 


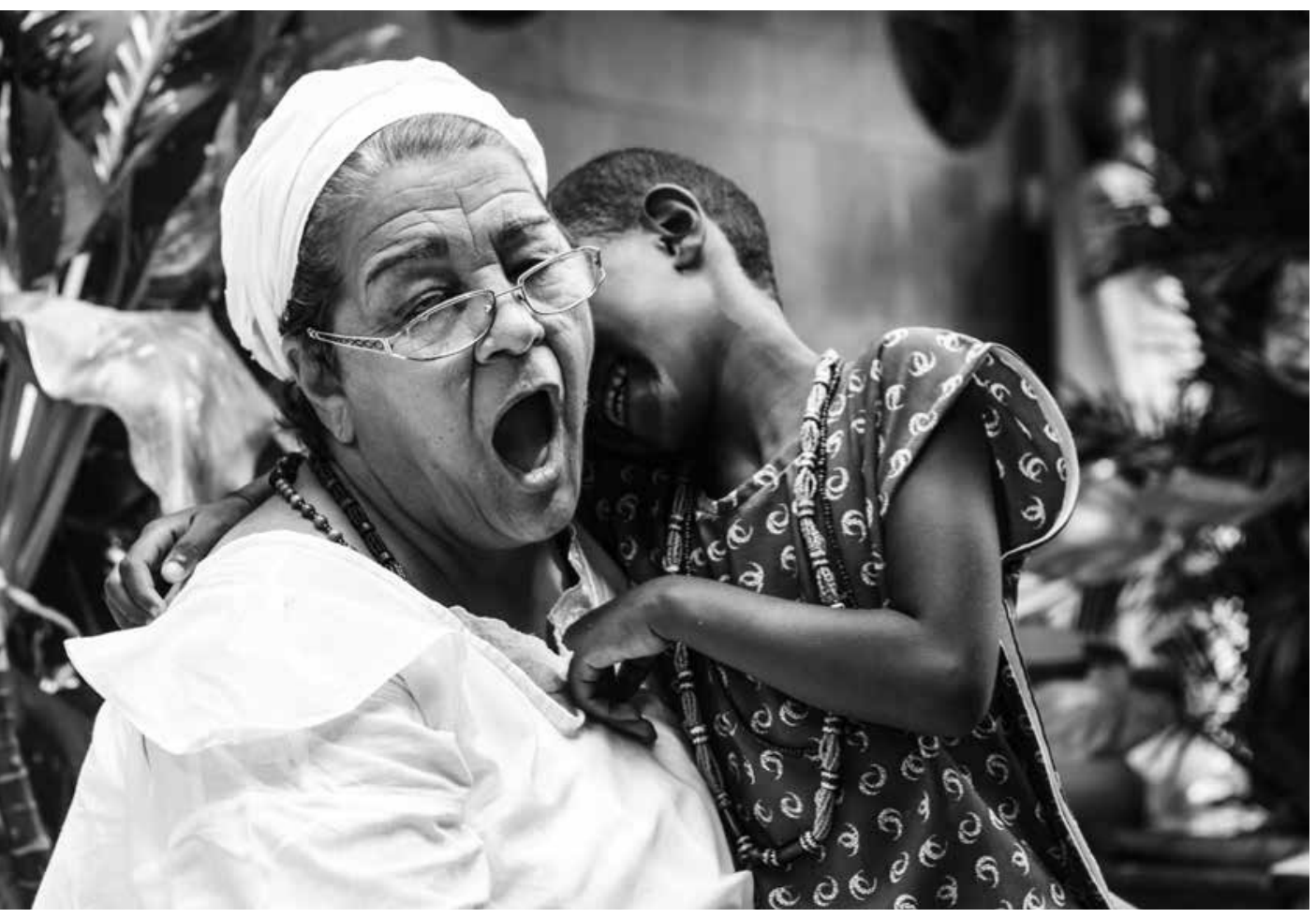

Figura 2 Mãe Odiléa e Cauã Esteves Foto: Stela Guedes Caputo

Burke (2004) destaca que também poucos historiadores trabalham em arquivos fotográficos, comparado ao número desses estudiosos que trabalham com documentos escritos. "Quando utilizam imagens, os historiadores tendem a tratá-las como meras ilustrações, reproduzindo-as nos livros sem comentários. Nos casos em que as imagens são discutidas no texto, essa evidência é frequentemente utilizada para ilustrar conclusões a que o autor já havia chegado por outros meios, em vez de oferecer novas respostas ou suscitar novas questões". (BURKE, 2004, p.12).

$\mathrm{O}$ autor enfatiza estar primordialmente interessado nas imagens como evidência histórica, encorajando seu uso como tal e também advertindo a respeito dos perigos desse procedimento. Para Burke, texto e imagens são fontes históricas e, tanto um quanto o outro, precisam ser criticados, antes de aceitos como evidências. A sugestão oferecida por ele nos parece bastante acertada e nos desvia da cansativa e improdutiva dicotomia em torno do assunto. Sim, acreditamos que fotografias podem ser fontes históricas e etnográficas. E não, não somos inocentes a 
ponto de entender a fotografia como uma mimese da realidade. Interroguemos as fontes como nos aconselha Burke.

\section{1 - Fotografar, ouvir, anotar}

Fazer fotos no campo tem sido fundamental nas pesquisas com crianças de terreiros, como dissemos, desde a matéria publicada em 1992, no Jornal O Dia. Seja quando pressionamos o dedo indicador no botão de disparo da máquina fotográfica, quando unimos indicador e polegar para anotar no caderno de campo e quando quase todos os dedos trabalham juntos para digitar as impressões e interpretações do que foi visto, ouvido e anotado, tudo se configura em um mesmo ato político.

Qualquer pesquisador que estude o candomblé conhece o trabalho de Pierre Verger, ainda que não fotografe. Se, contudo, a pesquisa desenvolvida utiliza a fotografia como parte da etnografia, o trabalho de Verger é referência e inspiração. Por óbvio, não nos referimos aqui ao extraordinário e incomparável talento artístico de Verger, mas sim, ao método desenvolvido por ele ao fotografar o campo pesquisado e mais, ao fazer texto e fotos se completarem na pesquisa. Mas nem
Figura 3

Mãe Odiléa e Cauã Esteves Foto: Stela Guedes Caputo

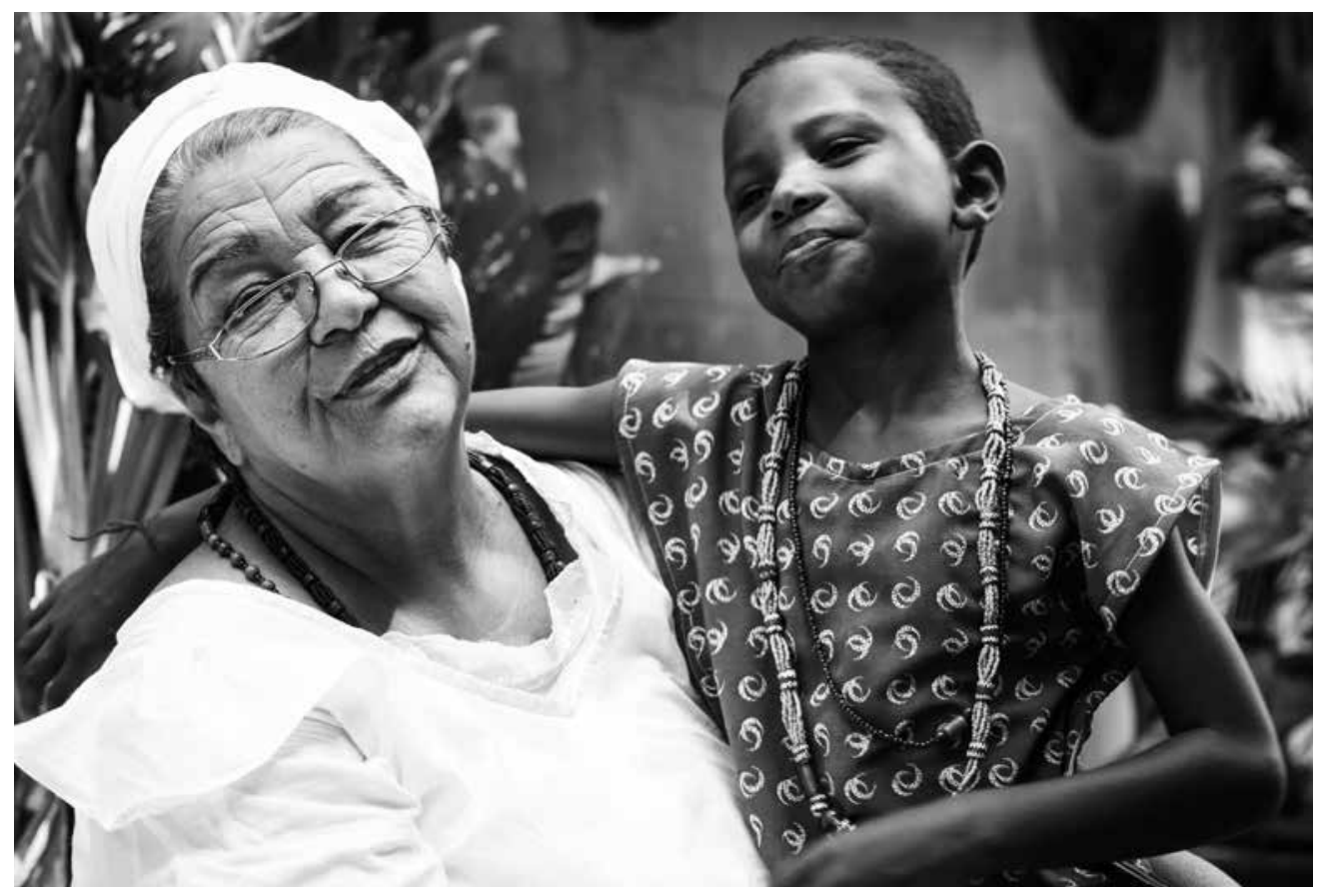


sempre foi assim, Souty (2011) explica que Verger no início foi exclusivamente fotógrafo e só depois etnógrafo, aliás, função que exerceu não sem muita resistência.

Sem a pretensão de esgotar o real, sua obra não desenha um sistema fechado de interpretação - pelo contrário, abre-se a outras possibilidades. Não se trata apenas de um trabalho científico, mas de um olhar sobre o mundo e as sociedades humanas, e também de um olhar reflexivo sobre si mesmo e a cultura ocidental. Homem de imagem, Verger acabou escrevendo sobre as culturas orais em que viveu. $\mathrm{O}$ que isso significa? Ele próprio experimentou três regimes de saber totalmente diferentes: imagem, escrita, oralidade - três meios de aprender a realidade ou transmitir um saber associados a visões de mundo distintas. (SOUTY, 2011, p. 13).

Durante muito tempo lemos os textos de Verger. Seu trabalho minucioso em descrever os cultos afro-brasileiros, seu esforço incansável de aproximar Brasil e África, em especial, as culturas iorubás foram e são fundamentais. Do mesmo modo, observamos suas fotos demorando-nos nos detalhes, vendo, revendo, sempre descobrindo coisas novas. Como desviar o olhar da foto do Elegun de Xangô, publicada em "Notas sobre o culto aos Orixás e Voduns" (2012)? Quase impossível. Tudo importava nas pesquisas de Verger e essa importância vinha do que mais tarde Souty chamou de "tríptico", ou seja, as fontes visuais, textuais e orais, suas três comparsas.

É com todas essas fontes que lidamos no campo, mas, em geral, é primeiro com fotografia que "anotamos" o campo. Das 40 fotos que levamos para a exposição referida nesse texto, escolhemos uma sequência de três fotos feitas no dia 12 de fevereiro de 2011, quando participamos de um ritual no Ilé Omo Oya Legi, em Mesquita, na Baixada Fluminense. Nesse dia estávamos mais perto do lugar do oferecimento ritual e mais distante do momento que a fotografia revela. Podíamos ver o que acontecia, mas não podíamos ouvir.

Nas imagens escolhidas e deixadas na primeira parte desse texto, Mãe Odiléa e Cauã Esteves disputam um com o outro quem sabe cantar mais certo uma determinada cantiga. A "mais velha", aprende com seu "mais novo" e vice-versa. Fotografamos porque o momento nos revelou um modo fundamental de se trocar saberes nos terreiros, modo para o qual sempre apontamos. Importava não perder a brincadeira entre os dois, não perder o movimento da boca de um, da boca do 
outro. Importava não perder o braço do menino em torno do pescoço de sua mais velha. O que diziam, poderíamos "recuperar" logo depois e anotar. Se perdêssemos o momento, perderíamos também a foto.

Como dissemos, não achamos produtivas as dicotomias sobre as quais discutíamos há pouco. Santaella (2014), por exemplo, diz que as imagens são tanto óbvias como astuciosas, reconhecendo mais um nível desta última classificação na sua capacidade duplicadora e multiplicadora de mundos.

Não se trata aqui simplesmente da natureza do duplo enquanto réplica figurativa de coisas visíveis fora da imagem, mas de algo menos óbvio: os modos pelos quais as imagens vão povoando o mundo de outros mundos, ou seja, aqueles que a imagem cria, recria, reproduz, emula, simula e multiplica. À realidade, as imagens aderem, criando e transmutando modos de ver. Longe de serem meros reflexos ou espelhos da realidade, as imagens são acréscimos, excedentes, adensando a complexidade do real. (SANTAELLA, 2014, p.15).

Durante a exposição conversamos com muitas pessoas sobre essa e outras imagens exibidas. Algumas queriam saber mais informações sobre várias fotos, inclusive sobre a sequência que trouxemos. Aos que demonstravam interesses por informações mais pormenorizadas também as podíamos dar. $\mathrm{O}$ dia em que foi feita, onde, quem são as pessoas, de que ritual de tratava. Havia também os que gostavam de saber a técnica utilizada e também sobre isso conversávamos. E a esse respeito cabe ressaltar que atualmente, em função de inúmeros recursos tecnológicos e aplicativos digitais, quase nada na produção das imagens é secreta. Ao fazer a captura da foto, os dados EXIF (Exchangeable image file format, ou formato de arquivo de imagem intercambiável) das digitais registram tudo: data, hora e autor da fotografia. Registram ainda os recursos utilizados pelo fotógrafo: a sensibilidade (ISO), a abertura do diafragma, velocidade do obturador, o tipo de máquina empregada. Mesmo que estes recursos fiquem disponíveis apenas ao autor da foto, existem aplicativos que são capazes de revelar tudo isso a quem interessar descobrir se a foto estiver acessível.

Foi um momento importante saber como as imagens seriam recebidas tão independentes do contexto em que foram feitas e tão liberadas dos textos que sempre as acompanharam. Nos ajudou a entender que as diferentes maneiras de ver, interrogar ou não interrogar as imagens revelam que do 
alto de seus 176 anos, a fotografia cumpriu seu único destino: não se reduzir ao que se pensou, se pensa e se pensará dela por outros 176 anos. Pelo pouco ou quase nada que já se fez a respeito das fotografias de crianças de terreiros, acreditamos que esse imenso e rico campo tanto para a arte fotográfica, para a antropologia, a história e para a educação, tem muito a contribuir nesse caminho.

\section{Das Nakirigrafias, dos movimentos e das travessias: estudantes de Forecariá e o diálogo com as suas fotografias}

A segunda exposição fotográfica, que é tema deste artigo, intitula-se "Nakirigrafias: narrativas de uma África", de Curadoria e Projeto de Geoésley Negreiros Mendes, com fotos produzidas por 12 estudantes da Escola III de Forecariá - Guiné-Conacri, África.

A ideia da nakirigrafia baseia-se em uma narrativa Baga de um dos povos que predominavam o Kalum antes da chegada dos colonizadores europeus. O Kalum, conforme nos conta Rivière4 (apud MENDES, 2015, p. 24, 25), é um território peninsular, com algumas ilhas à sua ponta, que oferecia importantes motivos de encontros entre povos daquele território. Mas o principal era a fertilidade daquela terra que alimentava tanto o corpo quanto o espírito das pessoas. Com o tempo - e os movimentos migratórios, também de outros povos oriundos de outros territórios africanos - o trânsito e as trocas foram se intensificando cada vez mais e o Kalum se tornou importante caminho de passagem: daqueles que já moravam na Península, e de outros que chegavam ali de outros lugares.

A península começou a ser povoada por uma mulher, de nome Tombo Ali. Ela teve um filho de nome Khamfori Ali. Este foi considerado o primeiro morador de um dos primeiros vilarejos da península, chamado Nongô, o berço do clã Bangurá.

Mais tarde, outro filho deste clã - Khamfori Kha - foi morar há poucos quilômetros de onde Khamfori Ali morava - próximo à foz do riacho Kaporô, "nascedouro" em língua baga, lugar que se tornou mais tarde um vilarejo da península.

A partir de alianças entre clãs baga, Kaporô começou a se expandir e passou a ser a capital da península. Entre esses acordos nasceram outros homens. Um chamado de Khamfori Massa e outro Khamfori Konan. Enquanto o primeiro continuara residindo em Kaporô, o segundo mudou-se para uma das ilhas que ultrapassa a península rumo ao mar. 
Embora tenha se mudado, Khamfori Konan mantinha-se em trânsito, indo e vindo com frequência de um lado a outro, da ilha à península. O outro lugar para o qual se mudou também tinha uma terra muito fértil - tanto quanto o Kalum - a ponto de também possibilitar o crescimento de dendezeiros que produziam ótimo vinho de dendê5.

Essa bebida afetava tanto quem a experimentava que quando se queria beber um bom vinho, ia-se à também terra do Konan. Por conta desse lugar e dos frutos de sua terra, este homem se tornou muito conhecido, a ponto dos moradores da península - a fim de conseguir a preciosa bebida e o que mais ela lhes proporcionava - realizarem a passagem para a ilha com muita frequência.

Na cultura Sosso, a do povo que chegou e trouxe à península sua língua e sua forma de compreender o mundo, nakiri tem sentido de "o outro lado", talvez mais voltado ao espaço. E nakirikai, "os moradores do outro lado", possivelmente sentido mais relacionado a uma história/tempo do/no espaço.

Importante salientar que no encontro dos Sosso com os povos que habitavam o Kalum, ao se enunciar, eles passam a existir para os outros (FANON, 2008, p. 33) que ali estavam. Dessa forma, os Sosso também diziam como se compreendiam naquele mundo. Possivelmente era como nakirikai que eles se viam/se sentiam porque eram populações em deslocamento, em travessias, vindo das terras de Krina ${ }^{6}$ localizadas no antigo Império do Mali (NIANE, 1982).

No contexto do Kalum, ser nakirikai não dependia apenas de onde se estava, mas também de seus deslocamentos/movimentos. Com os novos sentidos produzidos em diálogo com a cultura sosso, os nakirikai eram então as pessoas que estavam em trânsito na península - ou dentro da península, ou indo/ voltando da Ilha do Konan. Portanto, nakirikai eram todas as pessoas em situação de travessias/passagens.

A capital da Guiné ${ }^{7}$ parece ter passado a se chamar Konakry (Conacri), por ser vista como um território de nakirikai. Assim, concordando com Rivière (apud MENDES, 2015), seria possível estender o sentido de nakirikai a todos os povos que ali moram até hoje; e, além disso, a todas as pessoas de qualquer outro lugar do mundo que estão em trânsito, sujeitos a/de encontros com outros, ou com algo, acontecimento ex-tranho, que está fora o lugar e em movimento, sempre.

Esta forma de estar no mundo, remete-nos ao sujeito da ex-periência que encontramos em Larrosa (2011). No exercício de pensar o nakirikai, considerando-o sujeito da ex-periência, ima- 
ginamos ser possível pensar na imprescindibilidade de um outro para que a travessia se dê também como um deslocamento mobilizador, cujo afetar-se provoque a busca de experiências e outros saberes, como um movimento contínuo de humanização.

$\mathrm{Na}$ linha de pensamento do teórico espanhol, é o "desconhecido" que $(\mathrm{m})$ permitirá o nakirikai prezar pelo princípio da passagem, da travessia, do caminho, do movimento, do deslocamento, em direção ao conhecimento/saber do outro. Vale ponderar então que um possível afetamento - mobilizador de um possível conhecimento - só aconteceria com quem está caminhando, se movimentando.

Esta mirada sobre a questão experiência coaduna-se com a ideia do encontro (PASSOS, 2014), pela ética e a estética que este acontecimento também suscita quando um sujeito é afetado por outro(s) - ou por algo - fazendo emergir dali saberes, relações, narrativas, e gerando conhecimento.

De alguma(s) forma(s) poderíamos pensar a ideia do encontro e da experiência como acontecimento, no qual o afetar-se pela palavra do outro gera a necessidade de emergência de sentidos, despertada em nós no momento em que a palavra do outro encontra a minha palavra. A palavra do outro que, mesmo tendo sido emitida por ele, diz respeito à nossa própria vida.

Bakhin (2006, p. 40) nos convida pensar que a nossa vida é plena de relações de caráter político, considerando que as palavras são tecidas a partir de uma multidão de fios ideológicos. Para o teórico russo, a palavra é um signo sempre carregado de sentido porque foi/está sendo configurada em parceria/conflito com um outro, um interlocutor. Este caráter da linguagem na palavra para Bakhtin - tecido sempre por meio da interação social - é essencialmente cultural e polifônico; ou seja, há nela (na palavra) sempre outras histórias - que se tecem e são tecidas - querendo ser contadas por diversas perspectivas.

Aqui nos interessaria estender a perspectiva bakhtiniana do signo polifônico à imagem técnica - produzida por meio de aparelhos (FLUSSER, 1989) - mais particularmente estender à fotografia. Por meio dessa perspectiva outras histórias sobre a escola e sobre a vida de criança, jovem, estudante, de um contexto de Guiné Conacri, foram contadas por 12 estudantes que participaram diretamente da pesquisa de Mestrado de Geoésley Mendes, durante o mês de fevereiro de 2014.

Foram essas fotografias, produzidas pelos estudantes no contexto de uma oficina de fotografias, que possibilitaram a reflexão em torno da condição de nakirikai: tanto do pesquisador no processo de produção do conhecimento - sujeito dos 
tantos deslocamentos e travessias que consistiram em experiências no processo da pesquisa, das quais a do Oceano Atlântico foi apenas uma dentre outras - quanto dos estudantes, vivendo a dinâmica dos deslocamentos provocados pelo encontro com o educador estrangeiro que os interpelava sobre o seu cotidiano registrado em fotografias.

Deslocamentos culturais, potência de criação estética, sempre em movimento/em trânsito/interação porque produzida por sujeitos de movimentos, transitórios, nakirikai, a fotografia consistiu neste processo da pesquisa como narrativa no que diz respeito à produção de sentidos. Discursos e contra-discursos - imagens - ali presentes e em diálogo. Narrativas imagéticas que convidam a pensar a alteridade de forma singular, possibilitando o diálogo - nas travessias - entre quem produz as fotografias e quem as encontra.
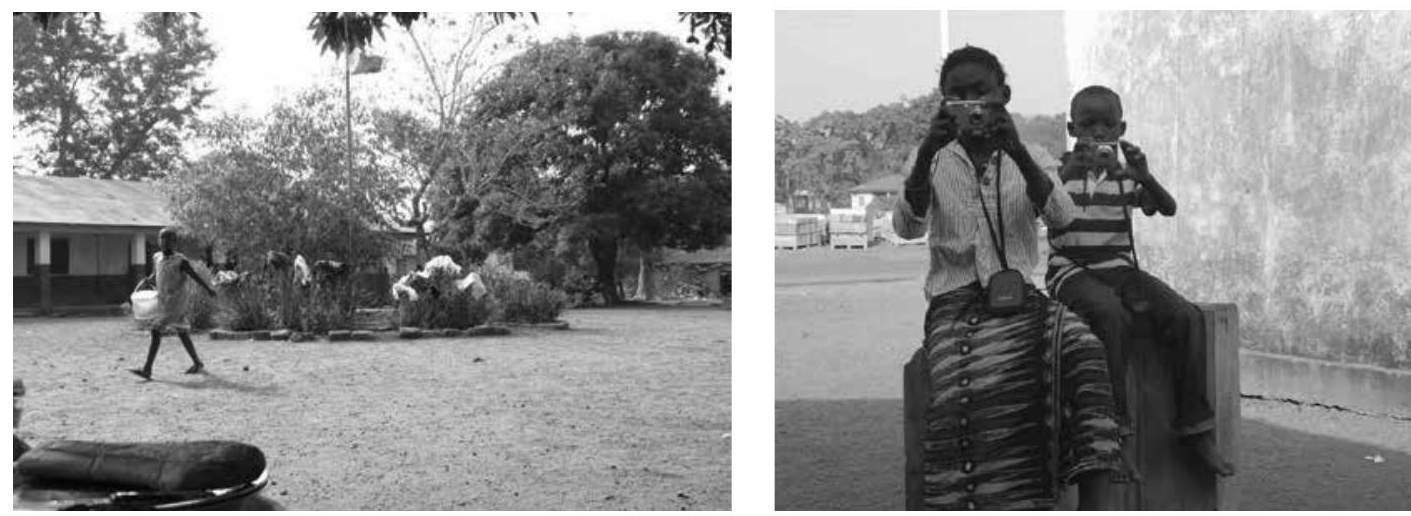

Assim, se a palavra fotografia, a partir do grego significa “escrita/desenho/narrativa” com luz, a produção em questão propõe-nos ser vista como nakirigrafias, isto é "escrita/desenho/narrativa" de nakirikai, dos "de outro lado" que estão em travessias/trânsito/movimentos/interação, com alusão aos sujeitos da narrativa baga.

Nesse sentido, as fotografias produzidas pelas/pelos estudantes da Escola III de Forecariá, Guiné-Conacri são enunciações que se propõem a contar outras histórias/imagens, de modo a provocar outros saberes de/com África, no diálogo com pessoas cujas vidas foram narradas por flashes e lentes geralmente eurocêntricas.

Se "falar é existir absolutamente para o outro", como nos ensinou Fanon (2008, p. 33) - porque é possibilidade do dizer-se, do enunciar-se para o outro - fotografar-se seria conferir-se

Figura 4

Fotografia do pátio da escola. Produção de David Beavogui, estudante do 6ano e participante da oficina de fotografias.

Figura 5

Dialiatore e Mohamed fotografando e sendo fotografados por Delphine Koto, outra participantes da oficina de fotografias, momentos antes de um encontro do grupo na escola. 
importância, parafraseando aquilo que Sontag afirma na epígrafe deste texto. A oficina de fotografias proposta aos estudantes teve estes objetivos: primeiramente o de contribuir para a desconstrução de uma perspectiva eurocêntrica em relação às imagens dos sujeitos que fotografaram; e ainda o de conhecer seu cotidiano por suas lentes, conhecer o que importa para eles.

Tentativa de dar-lhes um acabamento, mesmo sabendo que este é sempre provisório e carregado de incompletude. A ideia do excedente de visão (BAKHTIN, 2003) nos é muito cara para essa reflexão. É a possibilidade que eu tenho de ver o outro (e vice-versa) de uma maneira que ele não tem condições de se ver já que a visão que cada um tem de si é sempre parcial. Esse movimento, arriscaríamos pensar, não pode ser potencializado em travessias? Só o outro é capaz de ver-nos de forma a dar-nos o "acabamento".

Como diz o próprio autor:

urge que o excedente de minha visão complete o universo do outro indivíduo contemplado [...] . Eu devo entrar em empatia com esse outro indivíduo contemplado, ver axiologicamente o mundo de dentro dele tal qual ele vê, colocar-me no lugar dele e, depois de ter retornado ao meu lugar, completar o horizonte dele com o excedente de visão que desse meu lugar se descortina fora dele (BAKHTIN, 2003, p.23).

Exercício de acabamento (BAKHTIN, 2003) que existiu durante a pesquisa e que se renova a cada vez que alguém tem contato com as imagens produzidas pelos estudantes, nos levando abrir mão da previsibilidade, da ortodoxia, e nos convidando a negociar sentidos em/de diversos campos - inclusive de nossa vida - que dizem respeito tanto à produção de conhecimento como sobre nós mesmos. Exercício ético e estético: afetar-se pelas narrativas fotográficas dos nakirikai da pesquisa.

Numa perspectiva bakhtiniana, o que o tu percebe do eu, e vice-versa, numa relação, marca, portanto, a incompletude, o inacabamento de ambos, e sua humanidade. Isso significa que a cada fotografia que nos chega deste outro, nos mobiliza e nos convida a pensar que a relação do pesquisador com os estudantes, com a instituição e com sociedade local, até então inconsciente - de forma a pontuar sua impossibilidade de ser sujeito de si mesmo - desestabiliza e problematiza possíveis estereotipias em relação a uma ideia fixada de África e de escola africana, problematizando uma tentativa de estereotipia de 


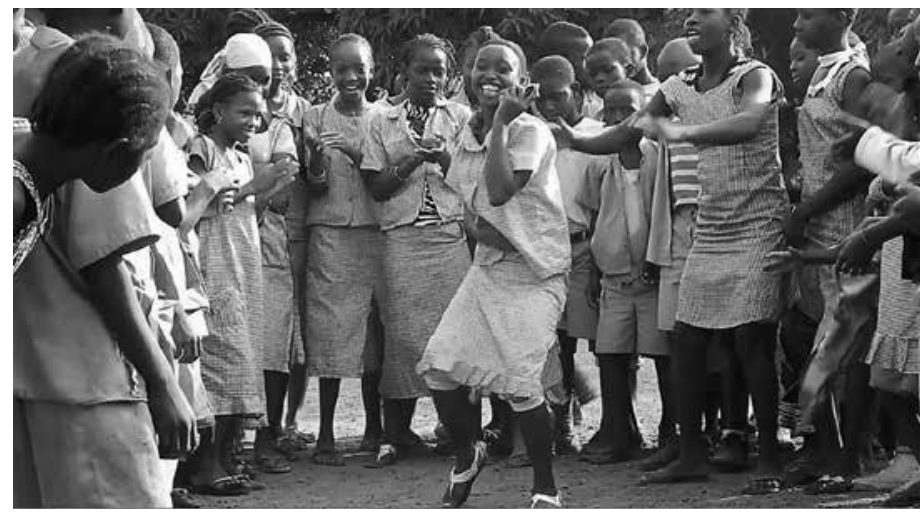

uma ideia do cotidiano dessas crianças. Tudo isso enunciado [como imagens] nas fotografias que as crianças produzem que longe de serem "verdades" - são exercícios de ver e de dar importância.

A partir das imagens produzidas pelos/pelas estudantes, a escola passa ser perseguida em vista de ser compreendida não mais pela sua perspectiva inicial estereotipada, mas como cronotopo $^{8}$ de reflexividade. Narrativas que são fabulações de um cotidiano possível, território de complexidades e sonhos, um cronotopo de disputa ideológica, e polifônico (BAKHTIN, 2003), de produção e interação de conhecimentos e culturas.

Mas, afinal, escola é coisa de branco? Como a escola aparece nas suas histórias/imagens? Foram perguntas feitas aos 12 estudantes do $4^{\circ}$ ao $6^{\circ}$ ano de uma escola pública da cidade de Forecariá9. De que maneiras, com uma máquina fotográfica à mão, a escola apareceria em suas histórias/imagens de vida fotografadas?

A fim de encontrar resposta para esta pergunta, a fotografia foi proposta na pesquisa de forma a exercer um papel político, e ideológico, funcionando hegemonicamente como instrumento de comprovação e denúncia dessa "máquina de produzir brancos" - alusão à Alvarez-Uria, 1992. Numa perspectiva predatória de produção e uso de fotografias na contemporaneidade.

É preciso que se lembre que a hipótese do pesquisador na oportunidade da oficina era que a escola seria fabulada nas fotografias a serem produzidas pelos/pelas estudantes pelo viés dele, pesquisador; ou seja, somente para confirmar o que, com muita fixação, foi buscar no campo da pesquisa a partir de sua experiência: uma escola totalmente pautada na obediência/ submissão ao discurso colonial, de caráter determinista, que desconsidera as experiências e interações sociais dos sujeitos
Figura 6

Cena de um vídeo produzido por Geoésley Mendes no pátio da escola da pesquisa. 
que a 'habitam' e por ela transitam. Essa hipótese é totalmente derrubada pela produção fotográfica dos/das estudantes.

Para surpresa, a grande maioria das fotografias produzidas $^{10}$ pelos sujeitos da pesquisa, durante 30 dias, pouco mostrava o que o pesquisador foi buscar no campo. E quando nelas encontrava o que lhe interessava pra discussão de seu tema, isto aparecia interagindo/ negociando com outras perspectivas/saberes, de forma a ampliar suas possibilidades de compreensão da escola, que antes escapavam. Nesse caminho, percebemos que a vida e as relações em uma escola naquele contexto guineano - o que nos convida pensar em outros - são muito mais complexas do que uma tendenciosa macronarrativa ideológica diz sobre ela(es).

As indicações da produção fotográfica dos sujeitos da pesquisa funcionaram, portanto, como dispositivos de deslocamento e interação no campo político e epistemológico a fim de nos levar compreender melhor a escola, e vida - por outro viés, plausivelmente diferente do que era deduzido a partir de perspectivas esperadas e totalitárias.

Esta experiência de pesquisa com fotografias que por ora compartilhamos nos faz compreender as nakirigrafias, contrapondo à ideia de um instrumento de comprovação/fixação/registro/exaltação de um significado/perspectiva que se pretende dominante, já mencionado, a partir de três categorias: uma, da linguagem que "dá acabamento" (BAKHTIN, 2003) à ideia/existência sempre incompleta/ambivalente, em constante diálogo (neste caso particular com a escola); outra, de território de interação/diálogo entre saberes - tal qual o Kalum e o pátio da escola - nos apontando como questões para a compreensão do ambiente escolar; e mais outra, do que Bhabha (1998) chama de prerrogativa pós-colonial (p. 77), cujo convite lançado por estas potencializa a busca política de releitura/negociação da "colonização"/dominação, mostrando-nos seu caráter de inacabamento. Vale ponderar que entendendo melhor o prefixo "pós" pelas perspectivas de alguns estudiosos, dentre estes Bhabha (1998; 2011), Hall (2003) e Fanon $(1979 ; 2008)$ podemos pensar nas relações socioculturais, e etnicorraciais, portanto, a partir de um conflito travado necessariamente entre ambas as partes das relações.

De acordo com Bhabha (1998), o horizonte das enunciações pós-coloniais se direciona a um discurso/prática produzido e apresentado por pessoas que supostamente jamais se enunciariam; ou seja, não teriam credibilidade diante da ditadura do discurso colonial/científico moderno/globalizador. 
Ainda aprendemos com Bhabha que as enunciações pós-coloniais - prerrogativas pós-coloniais - , como uma das condições do pós-colonialismo, geralmente vai de encontro ao que é colonial - podendo inclusive promover encontro entre estes que se enunciam e o que ele chama de burguesia colonial, aqueles que tentam impor suas verdades, suas leis.

Recorremos mais uma vez à Larrosa (2011) para pensar que as prerrogativas pós-coloniais trabalham então no sentido de provocar um afetamento e uma reflexividade em direção àquilo que falta ao que ocupa o suposto lugar do acabamento, oferecendo-lhe oportunidade de pensar a sua condição de sujeito composto e compositor de redes de subjetividade, de conhecimento e cultura.

Entendemos assim que as enunciações pós-coloniais discursos, práticas, e as nakirigrafias - servem como dispositivos que geram um novo conhecimento sobre o que é posto como verdade inquestionável, fixado pela filosofia colonial.

Nesse caminho, a perspectiva de diáspora negra trazida por Gilroy (2001), qual seja, os movimentos engajados numa política de subversão, ambivalência, criação, transformação, deslocamento e ressignificação, por sua vez, parece caminhar de mãos dadas com a de prerrogativas pós-coloniais de Bhabha (1998).

Temos aqui, então, algumas perspectivas pelas quais refletimos sobre a produção e o uso (CERTEAU, 1998) de fotografias em nossas pesquisas, que nos permitem perceber que os estudantes da escola em Forecariá em diálogo conosco - e com os outros que tomam contato com as fotografias que produziram e que atravessaram o oceano para serem vistas - também nos oferecem alternativas de pensamentos a respeito do mundo e de suas relações.

A partir dessas outras enunciações imagéticas de/sobre África - as nakirigrafias - que não a partir do discurso/centro único, o da colonização europeia - cristalizador - temos mais uma forma de potencializar o trabalho que já vem sendo realizado também no Brasil de uma educação pós-colonial (BHABHA, 1998; HALL, 2003) no sentido de uma releitura/negociação com este determinismo eurocêntrico, e de um conflito/tensionamento travado necessariamente entre todas as partes da relação.

De que modo poderíamos contribuir com reflexões e diálogos que potencializem um tensionamento de conceitos estagnados de escola, de cultura, de arte, de currículo, de África, de populações negras brasileiras - e da vida - se não considerarmos relevante para tensionar os debates o que nossos interlocutores nos dizem e o que nos mostram? 
1. Na matéria eu digo dialeto, corrijo aqui pelo que é: yorubá é uma língua africana.

2. Nessa época ainda não assinava com o sobrenome Caputo.

3. Outros textos com os mesmos objetivos (aprender com crianças e jovens de terreiros e descrever seus modos de criar significados, aprender e ensinar em terreiros, tendo as próprias crianças e jovens como sujeitos de si e do mundo, aprender com elas como elas significam os terreiros, os Orixás, seus cargos, enfim seus modos de viver o axé), independente de quaisquer propostas de pesquisas ou ações de pesquisas, só voltariam a ser publicados, e também por Caputo, em 2006, sendo que agora como resultados de pesquisas. Trata-se de: Crescendo entre Orixás In: Políticas Educacionais Tecnologias e formação do Educador: Repercussões sobre a didática e as práticas de ensino.1 ed. Recife: Edições Bagaço, 2006, v.1, p. 2947. E de: Educação em terreiros de candomblé contribuiçõ̃es para uma educação multicultural crítica. In: EducaçãoIntercultural e Cotidiano Escolar.1 ed. Rio de Janeiro, 7 Letras: 7 Letras, 2006, v.1, p. 180-207. Ambas as publicações sem imagens, o que só aconteceria com a publicação de Educação nos Terreiros - e como a escola se relaciona com crianças de Candomblé, Pallas, 2012, da mesma autora.

4. O texto original, em francês, está disponível em: <http://www.webguinee.net/bibliotheque/ethnographie/riviere/toponymie_cky_kalum.html>. Acesso em: o3 fev. 2015.

5. Segundo a narrativa Baga, os povos do Kalum tomavam vinho de palma que, numa tradução mais próxima para o português brasileiro, entendemos como um tipo de vinho, ou suco de dendê, diferente do óleo ou azeite de dendê, de maior.

6. Aqui me remeto à histórica Batalha de Kirina, quando o rei Soso a perde e deve deixar a terra com parte de seu povo.

7. Precisamos destacar que a Guiné da qual falamos é uma das três que existem atualmente no continente africano. Conhecida também como Guiné-Conacri - se diferenciando de Guiné-Bissau ("portuguesa”) e Guiné Equatorial ("espanhola") - faz fronteira com, entre outros países, Senegal, Mali, Costa do Marfim, Serra Leoa e Guiné-Bissau.

8. A filosofia bakhtiniana tem marcado nossa escolha política e epistemológica no contexto dos estudos que o Grupo de Pesquisa "Culturas e Identidades no Cotidiano" desenvolve. Mikhail Bakhtin chama de cronotopo a ligação intrínseca das relações temporais e espaciais que são artisticamente expressas na literatura e que compreendemos que também possa existir no universo social. $\mathrm{O}$ cronotopo seria assim as marcas do tempo expressas no espaço e sua dinâmica, que implica em um deslocamento. Deslocamento observável também nos sujeitos que habitam este cotidiano.

9. Cidade-capital de uma das 33 prefeituras de Guiné (equivalente aos estados brasileiros), localizada no sudoeste do país, há $100 \mathrm{~km}$ da capital da Guiné. Esta cidade se torna campo da pesquisa de Geoésley por conta de sua primeira experiência no país, a partir de onde surge seu interesse de pesquisa.

10. Ao todo, o grupo produziu quase 2.350 fotografias. Na dissertação de mestrado de Geoésley é possível visualizar parte dessa produção, especialmente as 60 fotografias que compuseram os álbuns de fotos do grupo, confeccionados ao longo da oficina.

\title{
Referências
}

\author{
ALVAREZ-URIA, Fernando; VARELA, Julia. A maquinaria \\ escolar. Tradução Guacira Lopes Louro. Revista Teoria $\mathcal{E}$
}


Educação, Porto Alegre, n. 6, 1992.

BAKHTIN, M. Estética da criação verbal. Tradução feita a partir do francês por Maria Ermantina Galvão G. Pereira. São Paulo: Martins Fontes, 2003.

BHABHA, Homi K. O local da cultura. Tradução Myriam Ávila, Eliana Lourenço de Lima Reis, Gláucia Renate Gonçalves. Belo Horizonte: Ed. UFMG, 1998.

. Interrogando a identidade: Frantz Fanon e a prerrogativa pós-colonial. In: O local da cultura. Tradução Myriam Ávila, Eliana Lourenço de Lima Reis, Gláucia Renate Gonçalves. Belo Horizonte: Ed. UFMG, 1998.

BURKE, Peter. Testemunha ocular: história e imagem. São Paulo: EDUSC, 2004.

CAPUTO, Stela G. Educação nos Terreiros - e como a escola se relaciona com crianças de Candomblé, Rio de Janeiro: Pallas, 2012.

CERTEAU, M. De. A invenção do cotidiano: artes de fazer. Petrópolis: Vozes, 1998.

DUBOIS, Philippe. O ato fotográfico. São Paulo: Papirus, 2006

FANON, Frantz. Pele negra, máscaras brancas. Trad. Renato da Silveira. Salvador: EDUFBA, 2008.

Os condenados da terra. 2. ed. Rio de Janeiro: Civilização Brasileira, 1979.

FLUSSER, V. Ensaio sobre a fotografia: para uma filosofia da técnica. Lisboa: Relógio D’água, 1989.

GILROY, Paul. O Atlântico Negro: modernidade e dupla consciência. Tradução de Cid Knipel Moreira. São Paulo: Ed. 34. Rio de Janeiro: Universidade Cândido Mendes, Centro de Estudos Afro-Asiáticos, 2001.

HALL, Stuart. Da diáspora: identidades e mediações culturais. Belo Horizonte: Editora UFMG; Brasília: Representação da UNESCO no Brasil, 2003.

LARROSA, Jorge. Experiência e Alteridade em Educação. Revista Reflexão e Ação, Santa Cruz do Sul, v.19, n. 2, p.04-27, jul./dez. 2011.

MENDES, Geoésley José Negreiros. Nakirigrafias como potencializadoras de compreensão da escola em/a partir de Guiné Conacri/África. 2015. 163 f. Dissertação (Mestrado em Educação) - Faculdade de Educação, Universidade do Estado do Rio de Janeiro. Rio de Janeiro, 2015. Disponível em:< www.proped.pro.br>. Acesso em: 27 ago. 2015

NIANE, Djibril Tamsir. Sundjata, ou, a epopeia mandinga. Tradução de Oswaldo Biato. São Paulo: Âtica, 1982. 
NOVAES, Sylvia Caiuby. O uso da imagem na antropologia. In: O fotográfico. SAMAIN, Etienne (Org). São Paulo: Editora SENAC, 2005.

PASSOS, Mailsa C. P. Encontros cotidianos e a pesquisa em Educação: relações raciais, experiência dialógica e processos de identificação. Educar em Revista, Curitiba, n. 51, p. 227-242, jan./mar. 2014.

SAMAIN, Etienne (Org.). Como pensam as imagens. Campinas: Editora da UNICAMP, 2012.

SONTAG, Susan. Sobre fotografia. São Paulo: Cia das Letras, 2004.

SOUTY, Jérôme. Pierre Fatumbi Verger: do olhar livre ao conhecimento iniciático. São Paulo: Editora Terceiro Nome, 2011.

TURAZZI, Maria Inez. Máquina viajante. In: Revista da Biblioteca Nacional, ano 5, n. 52, Janeiro, 2010.

Recebido em: 14/o9/15

Aceito em: 15/10/15 


\section{GEOÉSLEY NEGREIROS MENDES geoesley@hotmail.com} Mestre em Educação pelo Programa de Pós-Graduação em Educação da Universidade do Estado do Rio de Janeiro (UERJ), e vinculado ao grupo de pesquisa Culturas e Identidades no Cotidiano (UERJ).

\section{STELA GUEDES CAPUTO \\ stelaueri@gmail.com}

Doutora em Educação pela Pontifícia Universidade Católica do Rio de Janeiro (PUC-Rio) e professora do Programa de Pós-Graduação em Educação na Universidade do Estado do Rio de Janeiro (UERJ). Coordenadora do Grupo de Pesquisa Ilè Obà Óyó. Membro do Laboratório Educação e Imagem da UERJ. Autora do livro: Educação nos terreiros e como a escola se relaciona com crianças de Candomblé.

\section{MAILSA CARLA PINTO PASSOS \\ mailsappassos@gmail.com}

Doutora em Educação pela Pontifícia Universidade Católica do Rio de Janeiro (PUC-Rio). Professora da Faculdade de Educação, do Programa de Pós-Graduação da Universidade do Estado do Rio de Janeiro (UERJ). Membro do Laboratório Educação e Imagem da mesma Instituição.

Coordenadora do Grupo de Pesquisa "Culturas e Identidades no Cotidiano". Cientista do Nosso Estado da FAPERJ. 